\title{
Pelatihan Pengembangan Instrumen Tes Mata Pelajaran Matematika SMP
}

\author{
Anggit Prabowo ${ }^{1 *}$, Uus Kusdinar ${ }^{2}$, Uki Rahmawati ${ }^{3}$ \\ 1,2 Program Studi Pendidikan Matematika FKIP Universitas Ahmad Dahlan \\ ${ }^{3}$ South East Asian Ministers of Education Organization (SEAMEO) Qitep in Mathematics
}

A R T I C L E I N F O

Article history:

Received 15 March 2018

Received in revised form

13 May 2018

Accepted 29 June2018

Available online 24 August

2018

Kata Kunci:

tes;

matematika;

SMP

Keywords:

instrument;

test;

mathematics; junior high school.

A B S T RAK

Tujuan pengabdian kepada masyarakat ini adalah memberikan pelatihan kepada guru matematika SMP untuk mengembangkan instrumen tes matematika SMP. Peserta pelatihan ini terdiri atas 12 guru dari 4 sekolah yaitu SMP Muhammadiyah 1 Godean, SMP Muhammadiyah 1 Gamping, SMP Muhammadiyah 1 Minggir, dan SMP Muhammadiyah 2 Depok, Kabupaten Sleman, Daerah Istimewa Yogyakarta. Kegiatan ini dilaksanakan di SMP Muhammadiyah 1 Godean. Metode pelaksanaan kegiatan pengabdian adalah melalui ceramah, diskusi, dan proyek. Pada kegiatan ceramah pemateri meyampaikan materi tentang teknik pengembangan instrumen penilaian sesuai dengan prosedur yang baku dilanjutkan dengan diskusi. Setelah diskusi, peserta pelatihan mengerjakan tugas proyek berupa menyusun instrument tes mata pelajaran matematika SMP, menganalisis secara kualitatif, mengujicobakannya, dan menganalisis berdasar data empirik. Melalui pelatihan ini peserta memeroleh keterampilan dalam mengembangkan instrumen penilaian tes matematika SMP. Secara umum pelatihan ini telah berhasil. Hal ini ditunjukkan dari indikator pertama bahwa tingkat pemahaman peserta dalam mengembangkan instrumen tes mata pelajaran matematika SMP sebesar $85 \%$ dan indikator kedua yaitu tersusunnya instrumen tes pilihan ganda untuk mata pelajaran matematika SMP untuk materi perbandingan, hubungan antar sudut, dan bangun datar, yang terstanda.

\section{A B S T R A C T}

The purpose of community service is to provide training to junior high school teachers to develop mathematics test instrument. The participants were 12 teachers from 4 schools: SMP Muhammadiyah 1 Godean, SMP Muhammadiyah 1 Gamping, SMP Muhammadiyah 1 Minggir, and SMP Muhammadiyah 2 Depok, Sleman District, Yogyakarta Special Region. This activity was held in SMP Muhammadiyah 1 Godean. The method of this activity were through lectures, discussions, and projects. In the lecture the presenters presented the material on the developing technique of the assessment instrument in accordance with the standard procedure followed by the discussion. After the discussion, the trainees undertook the project task of composing the SMP mathematics test instrument, analyzing qualitatively, testing it, and analyzing based on empirical data. Through this training, participants gain skills in developing SMP mathematics test assessment instruments. In general, this training has been successful. This is indicated by the first indicator that the level of participants' understanding in developing junior mathematics subjects test instrument was $85 \%$ and the second indicator was the compilation of standardized multiple choice test instrument for junior mathematics subjects for comparison material, inter-angle relationship, and plain shape has been assembled

Copyright (C) Universitas Pendidikan Ganesha. All rights reserved.

\footnotetext{
* Corresponding author.

E-mail addresses: anggit.prabowo@pmat.uad.ac.id (Anggit Prabowo)
} 


\section{Pendahuluan}

Guru yang baik adalah guru yang memiliki kompetensi-kompetensi sesuai yang diamanatkan oleh undang-undang. Dalam Undang-Undang Nomor 14 Tahun 2005 tentang Guru dan Dosen disebutkan bahwa kompetensi yang wajib dimiliki oleh seorang guru meliputi kompetensi pedagogik, kompetensi kepribadian, kompetensi sosial, dan kompetensi profesional. Kompetensi pedagogik adalah kemampuan guru dalam mengelola pembelajaran peserta didik. Kompetensi kepribadian artinya guru harus memiliki kepribadian yang mantap, berakhlak mulia, arif, dan berwibawa serta menjadi teladan peserta didik. Kompetensi profesional artinya kemampuan guru dalam menguasai materi pelajaran secara luas dan mendalam. Kompetensi sosial mengandung pengertian bahwa guru harus memiliki kemampuan untuk berkomunikasi dan berinteraksi secara efektif dan efisien dengan peserta didik, sesama guru, orangtua/wali peserta didik, dan masyarakat sekitar. Salah satu kompetensi inti dalam kompetensi pedagogik guru menurut Peraturan Menteri Pendidikan Nasional Nomor 16 Tahun 2007 tentang Standar Kualifikasi Akademik dan Kompetensi Guru adalah menyelenggarakan penilaian dan evaluasi proses dan hasil belajar. Salah satu bentuk penguasaan kompetensi tersebut adalah bahwa sebagai seorang guru harus mampu mengembangkan instrumen penilaian dan evaluasi proses dan hasil belajar.

Penilaian yang baik adalah penilaian yang memenuhi prinsip-prinsip penilaian. Permendikbud Nomor 23 Tahun 2016 menyebutkan bahwa prinsip-prinsip penilaian yang dimaksud adalah: sahih, objektif, adil,terpadu, terbuka, menyeluruh dan berkesinambungan, sistematis, beracuan kriteria, dan akuntabel. Hal yang sangat mempengaruhi kualitas penilaian adalah instumen penilaian yang digunakan. Salah satu prosedur penilaian proses belajar dan hasil belajar oleh guru adalah melakukan analisis kualitas instrumen. Instrumen tersebut harus memenuhi persyaratan substansi, konstruksi, dan bahasa, memiliki bukti validitas, dan reliabilitas. Salah satu tahap pengembangan instrumen adalah analisis atau telaah instrumen (Mardapi, 2008). Analisis yang dilakukan meliputi analisis kualitatif dan analisis kuantitatif. Analisis kualitatif meliputi persyaratan substansi, konstruksi, bahasa, dan memiliki bukti validitas. Untuk analisis kuantitatif, analisis yang dilakukan meliputi tingkat kesulitan, daya beda, keberfungsian pengecoh, dan reliabilitas.Analisis kuantitatif dapat dilakukan dengan cara konvensional dan dengan menggunakan komputer. Analisis dengan cara konvensional adalah analisis yang dalam melakukan perhitungan-perhitungan statistiknya dilakukan secara manual. Cara ini memiliki kelemahan dimana proses yang dilakukan menjadi lebih lama dan rawan terjadi kesalahan. Kelemahan ini dapat diatasi dengan analisis berbantuan komputer. Analisis dengan cara ini lebih cepat karena semua perhitungan dilakukan oleh komputer dan sangat kecil terjadi kesalahan perhitungan. Dyah (2016) berpendapat bahwa Sampat saat ini banyak instrumen hasil belajar yang belum memenuhi persyaratan sebagai tes yang baik. Salah satu hal yang mungkin menjadi penyebabnya adalah kemampuan guru dalam membuat tes yang masih rendah sehingga pengukuran menjadi tidak akurat. "Tes merupakan instrumen untuk mengumpulkan data peserta yang memberikan respons terhadap pertanyaan agar peserta dapat menunjukkan kemampuan dan penguasaan maksimum yang dimilliki (Tenri,2018). Budi (2014) mengatakan bahwa "instrumen itu mempunyai fungsi dan peran yang sangat penting dalam rangka mengetahui keefektifan proses pembelajaran”. Pulungan (2014) berpendapat bahwa Instrumen tes literasi matematika model PISA Praktis kategori sangat baik dengan nilai sebesar 92\%.

Hasil wawancara dengan Sekretaris Majelis Dikdasmen PDM Gunungkidul menunjukkan bahwa selama ini masih jarang pelatihan yang dilakukan dari Dikdasmen untuk meningkatkan kompetensi guru khususnya dalam penyusunan dan analisis instrumen penilaian bagi guru-guru matematika (Prabowo, 2017). Karena hal tersebut, kemampuan guru dalam mengembangkan instrumen penilaian matematika masih kurang. Dengan kata lain, instrumen penilaian yang mereka kembangkan belum dapat diidentifikasi kualitasnya. Apabila hal ini terjadi, akan sangat mungkin guru melakukan kesalahan yang sistematis apabila ternyata instrumen yang digunakan tidak baik. Jika permasalahan kompetensi guru tidak segera dipecahkan maka akan menjadi permasalahan yang cukup berarti. Instrumen yang digunakan untuk mengukur kompetensi peserta didik tidak baik. Hal ini akan berakibat pada ketidaksahihan informasi tentang kompetensi peserta didik yang diukur guru. Oleh karena itu, permasalahan tersebut harus segera diatasi. Salah satu alternatif yang bisa dilakukan adalah memberikan pelatihan kepada guru-guru tentang bagaimana cara mengembangkan instrumen penilaian hasil belajar matematika SMP yang baku

\section{Metode}

Kegiatan pengabdian kepada masyarakat ini dilaksanakan pada tanggal 14 sampai dengan 15 Mei 2018. Peserta kegiatan ini adalah 12 guru dari 4 sekolah yaitu SMP Muhammadiyah 1 Godean, SMP Muhammadiyah 1 Gamping, SMP Muhammadiyah 1 Minggir, dan SMP Muhammadiyah 2 Depok, Kabupaten Sleman, Daerah Istimewa Yogyakarta. Metode yang digunakan terdiri atas 3 metode yaitu 
metode ceramah, diskusi, dan praktik. Metode pertama adalah ceramah. Narasumber kegiatan ini adalah 2 orang dosen pendidikan matematika FKIP UAD dengan bidang keahlian evaluasi pembelajaran matematika. Pada metode ini pemateri menyampaikan paparan tentang prosedur baku dalam mengembangkan instrumen tes. Menurut Mardapi (2008), prosedur pengambangan instrumen meliputi: 1) menentukan spesifikasi instrumen, 2) Menulis Instrumen, 3) Menentukan skala instrumen, 4) menentukan sistem pensekoran, 5) mentelaah instrumen, 6) melakukan ujicoba, 7) menganalisis instrumen, 8) merakit instrumen, 9) melaksanakan pengukuran, dan 10) menafsirkan hasil pengukuran.

Setelah pemaparan materi tentang prosedur pengembangan instrumen tes, metode yang kedua adalah peserta dan narasumber berdiskusi tentang teknik-teknik dalam mengembangan instrumen tes. Selanjutnya, metode ketiga, peserta pelatihan diminta mengerjakan tugas proyek untuk mengembangkan instrumen tes matematika SMP. Pada pelatihan ini, tidak semua kompetensi dasar matematika di SMP dibuat instrumen tesnya. Agar pembahasan lebih mendalam maka pemateri menentukan 3 kompetensi dasar yang akan dikembangkan instrument tesnya. Kompetensi dasar tersebut disajikan pada Tabel 1.

Tabel 1. Kompetensi Dasar

\begin{tabular}{|c|c|}
\hline Kompetensi Inti & Kompetensi dasar \\
\hline $\begin{array}{l}\text { 3.Memahami pengetahuan (faktual, } \\
\text { konseptual, dan prosedural) } \\
\text { berdasarkan rasa ingin tahunya } \\
\text { tentang ilmu pengetahuan, } \\
\text { teknologi, seni, budaya terkait } \\
\text { fenomena dan kejadian tampak } \\
\text { mata }\end{array}$ & $\begin{array}{l}\text { 3.8 Membedakan perbandingan senilai dan berbalik nilai } \\
\text { dengan menggunakan tabel data, grafik, dan persamaan } \\
\text { 3.10 Menganalisis hubungan antar sudut sebagai akibat dari dua } \\
\text { garis sejajar yang dipotong oleh garis transversal } \\
\text { 3.11 Mengaitkan rumus keliling dan luas untuk berbagai jenis } \\
\text { segiempat (persegi, persegi panjang, belah ketupat, jajargenjang, } \\
\text { trapesium, dan layang-layang) dan segitiga }\end{array}$ \\
\hline $\begin{array}{l}\text { 4. Mencoba, mengolah, dan menyaji } \\
\text { dalam ranah } r \text { konkret } \\
\text { (menggunakan, mengurai, } \\
\text { merangkai, memodifikasi, dan } \\
\text { membuat) dan ranah abstrak } \\
\text { (menulis, membaca, menghitung, } \\
\text { menggambar, dan mengarang) } \\
\text { sesuai dengan yang dipelajari di } \\
\text { sekolah dan sumber lain yang sama } \\
\text { dalam sudut pandang/teori }\end{array}$ & $\begin{array}{l}\text { 4.8 Menyelesaikan masalah yang berkaitan dengan } \\
\text { perbandingan senilai dan berbalik nilai } \\
\text { 4.10 Menyelesaikan masalah yang berkaitan dengan hubungan } \\
\text { antar sudut sebagai akibat dari dua garis sejajar yang dipotong } \\
\text { oleh garis transversal } \\
4.11 \text { Menyelesaikan masalah kontekstual yang be rkaitan } \\
\text { dengan luas dan keliling segiempat (persegi, persegi panjang, } \\
\text { belahketupat, jajargenjang, trapesium, dan layang-layang) dan } \\
\text { segitiga }\end{array}$ \\
\hline
\end{tabular}

Berdasar kompetensi dasar tersebut, maka terdapat 3 materi utama yaitu perbandingan, hubungan antar sudut, dan keliling dan luas segiempat dan segitiga. Selanjutnya peserta tes diminta untuk menyusun kisi-kisi tes berdasar kompetensi dasar yang ditentukan. Setelah menyusun kisi-kisi, peserta tes menulis redaksi soal, menentukan skala, dan menyusun pedoman penskoran. Setiap materi dibuat 5 soal pilihan ganda dengan 4 alternatif jawaban sehingga banyaknya butir soal yang dibuat ada 15 butir soal. Soal-soal yang telah ditulis oleh peserta selanjutnya ditelaah. Telaah yang dilakukan merupakan telaah kualitatif yang meliputi kesesuaian materi, konstruksi soal, dan bahasa yang digunakan. Setelah telaah sudah dilakukan dan dilakukan revisi, soal yang ditulis diujicobakan kepada siswa-siswa SMP di sekolah peserta pelatihan.

Data hasil uji coba selanjutnya dianalisis. Analisis dilakukan dengan bantuan program Item and Test Analysis (ITEMAN) untuk mengetahui karakteristik butir tes yang dikembangkan. ITEMAN adalah program yang dikembangkan oleh Assessment Systems Corporation (Pisowacka, 2015; Prabowo, 2017). Program ini sangat baik digunakan untuk menganalisis butir soal berbentuk pilihan ganda (Nur dan Palobo, 2018). Hasil dari analisi yang ditampilkan meliputi tingkat kesukaran, daya beda, dan statistic penyebaran jawaban, realibilitas tes (Rosana \& Setyawarno, 2016, Prabowo, 2017). Setelah karakteristik butir soal diketahui, selanjutnya dilakukan revisi sesuai dengan hasil analisis. Soal-soal yang sudah direvisi selanjutnya dirakit menjadi instrumen tes dan siap untuk digunakan untuk melakukan pengukuran.

Indikator keberhasilan kegiatan pelatihan ini ada dua. Indikator pertama adalah bahwa minimal $75 \%$ peserta pelatihan memiliki pemahaman cara mengembangkan instrumen tes mata pelajaran matematika sesuai prosedur yang baku yang diukur melalui angket dan wawancara. Indikator kedua adalah pelatihan ini mampu menghasilkan luaran berupa butir-butir instrumen tes mata pelajaran 
matematika SMP yang terstandar baku untuk materi perbandingan, hubungan antar sudut, dan keliling dan luas segiempat dan segitiga.

\section{Hasil dan pembahasan}

Kegiatan pengabdian kepada masyarakat pada hari pertama adalah pemateri memberikan materi tentang prosedur pengembangan instrumen penilaian kepada peserta pelatihan (gambar 1).

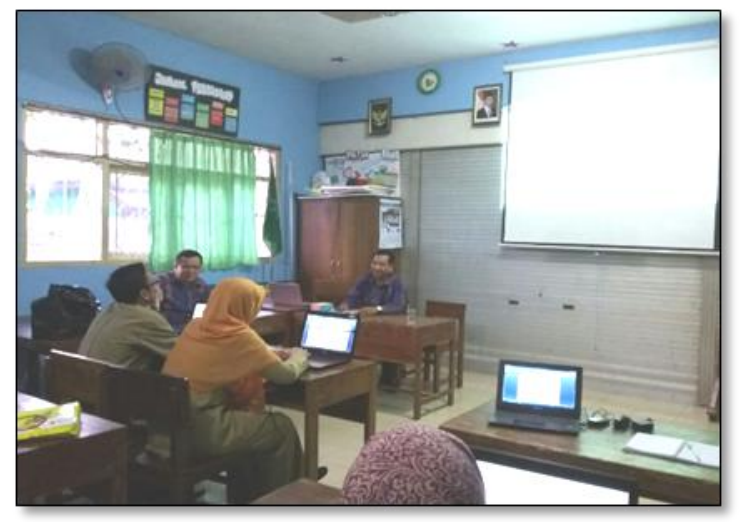

Gambar 1. Pemateri Menyampaikan Materi Pelatihan

Prosedur pertama dalam mengembangkan instrumen penilaian adalah menentukan spesifikasi instrumen. Dalam menentukan spesifikasi instrumen, pengembang tes harus menentukan tujuan pengembagan instrumen dan kisi-kisi instrumen. Di dalam kisi-kisi instrumen terdapat informasi mengenai identitas sekolah/materi, kompetensi dasar, indikator, level kognitif, nomor soal, dan bentuk soal. Bentuk soal yang akan dikembangkan adalah soal pilihan ganda. Gambar 2 adalah contoh format kisikisi.

\begin{tabular}{|c|c|c|c|c|c|c|}
\hline \multicolumn{7}{|c|}{ Contoh kisi-kisi } \\
\hline & \multirow{4}{*}{$\begin{array}{l}\text { Nama sekolah } \\
\text { Kelas } \\
\text { Tahun Pelajaran } \\
\text { Mata pelajaran }\end{array}$} & \multirow{2}{*}{\multicolumn{5}{|c|}{$\begin{array}{l}\text { SMP .................. } \\
\text { VII semester } 2\end{array}$}} \\
\hline & & & & & & \\
\hline & & \multirow{2}{*}{\multicolumn{5}{|c|}{ Matematika }} \\
\hline & & & & & & \\
\hline No & Kompetensi Dasar & Materi & Indikator & Level kognitif & No Soal & Bentuk soal \\
\hline \multirow[t]{4}{*}{1.} & \multirow[t]{4}{*}{$\begin{array}{l}4.8 \quad \text { Menyelesaikan } \\
\text { masalah yang berkaitan } \\
\text { dengan perbandingan } \\
\text { senilai dan berbalik } \\
\text { nilai }\end{array}$} & \multirow[t]{4}{*}{ Perbandingan } & $\begin{array}{l}\text { Diberikan permasalahan } \\
\text { nyata dalam kehidupan } \\
\text { sehari-hari, peserta didik } \\
\text { dapat menentukan } \\
\text { penyelesaian yang } \\
\text { berkaitan dengan } \\
\text { perbandingan senilai }\end{array}$ & & & \\
\hline & & & $\begin{array}{l}\text { Diberikan permasalahan } \\
\text { nyata dalam kehidupan } \\
\text { sehari-hari, peserta didik } \\
\text { dapat menentukan } \\
\text { penyelesaian yang } \\
\text { berkaitan dengan } \\
\text { perbandingan berbalik } \\
\text { nilai }\end{array}$ & & & \\
\hline & & & & & & \\
\hline & & & & & & \\
\hline
\end{tabular}

Gambar 2. Contoh format kisi-kisi

Apabila format kisi-kisi sudah dibuat, maka langkah pengembangan instrumen selanjutnya adalah menulis soal. Dalam menulis soal pilihan ganda, terdapat kaidah-kaidah yang harus dipenuhi dari aspek materi, konstruksi, dan bahasa. Kaidah yang harus dipenuhi dari aspek materi adalah sebagai berikut: 1) Soal sesuai dengan indikator, 2) Pilihan jawaban homogen dan logis ditinjau dari segi materi, 3) Soal mempunyai satu jawaban yang benar atau yang paling benar.

Kaidah yang harus dipenuhi dari aspek konstruksi adalah sebagai berikut; 1) Pokok soal (stem) dirumuskan secara singkat dan jelas, 2) Rumusan pokok soal berisi informasi yang diperlukan saja, 3) 
Pokok soal tidak memberikan petunjuk jawaban yang benar, 4) Pilihan jawaban disusun menurun, 5) Susunan pilihan jawaban apabila berupa angka disusun berdasar besar kecilnya. Apabila berupa peristiwa maka disusun berdasar kronologisnya, 6) Suatu butir soal tidak bergantung pada butir soal yang lain, 7)Tidak mengandung pernyataan negatif ganda, 8) Gambar, grafik, atau tabel disajikan secara jelas, dan 9) Butir soal tidak bergantung pada jawaban soal sebelumnya.

Kaidah yang harus dipenuhi dari aspek bahasa adalah sebagai berikut.

1. Soal menggunakan bahasa yang sesuai dengan kaidah bahasa Indonesia.

2. Tidak menggunakan bahasa yang berlaku setempat jika soal akan digunakan untuk daerah lain atau nasional.

3. Menggunakan bahasa yang komunikatif.

4. Soal yang telah ditulis selanjutnya ditelaah sesuai dengan aspek-aspek di atas dengan format telaah soal tersaji pada gambar 3 .

5.

\begin{tabular}{|c|c|c|c|c|c|c|c|c|c|c|c|c|c|c|c|}
\hline \multicolumn{16}{|c|}{ ANALISIS KUALITATIF/TELAAH BUTIR SOAL } \\
\hline \multirow[t]{2}{*}{ ASPEK YANG DIAMATI } & \multicolumn{15}{|c|}{ Nomor Butir Soal } \\
\hline & 1 & 2 & 3 & 4 & 5 & 6 & 7 & 8 & 9 & 10 & 11 & 12 & 13 & 14 & 15 \\
\hline \multicolumn{16}{|l|}{ Materi } \\
\hline \multicolumn{16}{|l|}{ 1. Soal sesuai dengan indikator. } \\
\hline \multicolumn{16}{|l|}{ 2. Pilihan jawaban homogen dan logis ditinjau dari segi materi. } \\
\hline \multicolumn{16}{|l|}{$\begin{array}{l}\text { 3. Soal mempunyai satu jawaban yang benar atau yang paling } \\
\text { benar. }\end{array}$} \\
\hline \multicolumn{16}{|l|}{ Konstruksi } \\
\hline \multicolumn{16}{|l|}{ 1. Pokok soal dirumuskan secara jelas dan tegas. } \\
\hline \multicolumn{16}{|l|}{$\begin{array}{l}\text { 2. Rumusan pokok soal dan pilihan jawaban merupakan } \\
\text { pernyataan yang diperlukan saja. }\end{array}$} \\
\hline \multicolumn{16}{|l|}{ 3. Pokok soal tidak memberi petunjuk ke arah jawaban benar. } \\
\hline \multicolumn{16}{|l|}{$\begin{array}{l}\text { 4. Pokok soal tidak mengandung pernyataan yang bersifat } \\
\text { negatif ganda. }\end{array}$} \\
\hline \multicolumn{16}{|l|}{ 5. Panjang rumusan pilihan jawaban relatif sama. } \\
\hline \multicolumn{16}{|l|}{$\begin{array}{l}\text { 6. Pilihan jawaban tidak mengandung pernyataan, "Semua } \\
\text { pilihan jawaban di atas salah" atau "Semua pilihan } \\
\text { jawabandi atas benar". }\end{array}$} \\
\hline \multicolumn{16}{|l|}{$\begin{array}{l}\text { 7. Pilihan jawaban yang berbentuk angka atau waktu disusun } \\
\text { berdasarkan urutan besar kecilnya nilai angka tersebut atau } \\
\text { kronologisnya. }\end{array}$} \\
\hline \multicolumn{16}{|l|}{$\begin{array}{l}\text { 8. Gambar, grafik, tabel, diagram, dan sejenisnya yang terdapat } \\
\text { pada soal jelas dan berfungsi. }\end{array}$} \\
\hline \multicolumn{16}{|l|}{ 9. Butir soal tidak bergantung pada jawaban soal sebelumnya. } \\
\hline \multicolumn{16}{|l|}{ Bahasa } \\
\hline \multicolumn{16}{|l|}{$\begin{array}{l}\text { 1. Soal menggunakan bahasa yang sesuai dengan kaidah } \\
\text { bahasa Indonesia. }\end{array}$} \\
\hline \multicolumn{16}{|l|}{$\begin{array}{l}\text { 2. Tidak menggunakan bahasa yang berlaku setempat jika soal } \\
\text { akan digunakan untuk daerah lain atau nasional. }\end{array}$} \\
\hline 3. Menggunakan bahasa yang komunikatif. & & & & & & & & & & & & & & & \\
\hline
\end{tabular}

Gambar 3. Format Telaah Soal

Hasil telaah soal tersaji pada gambar 4.

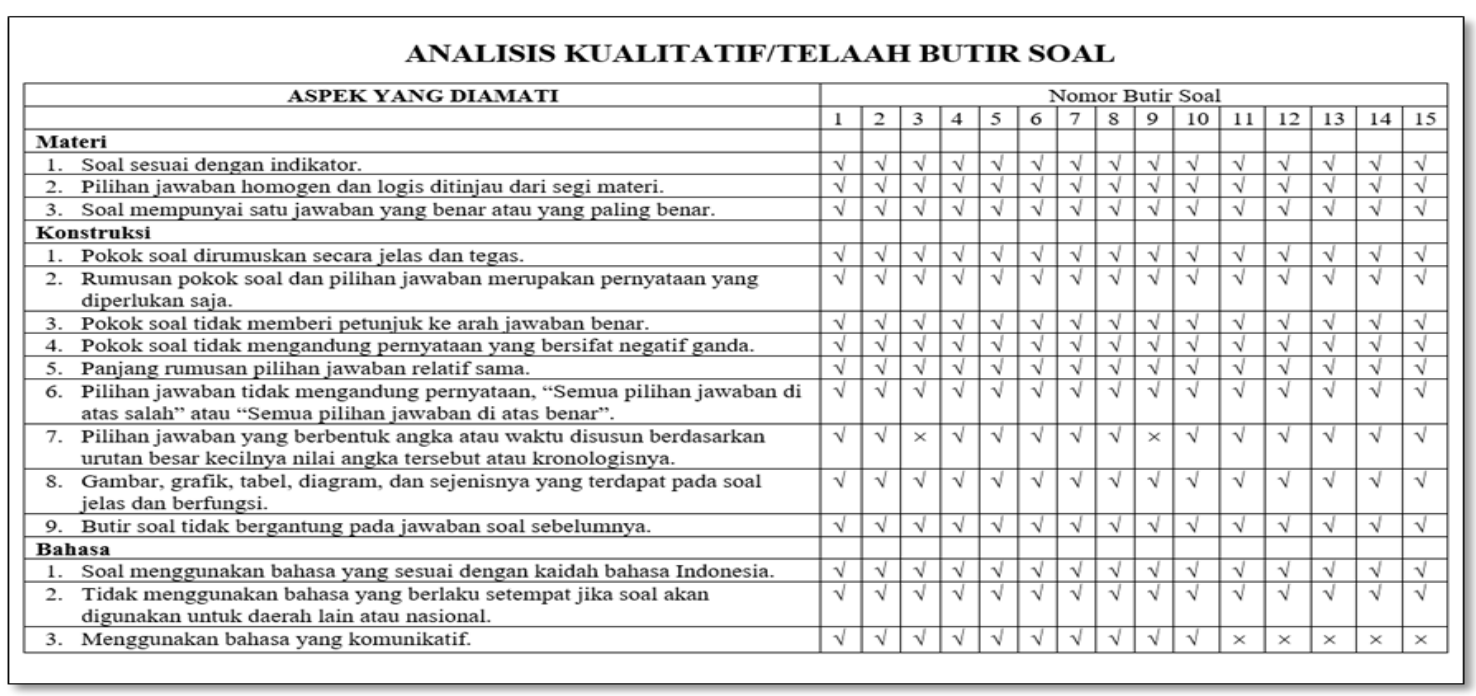




\section{Gambar 4. Hasil Telaah Soal}

Hasil telaah menunjukkan bahwa terdapat 7 butir soal yang tidak sesuai dengan kaidah penulisan soal. Soal nomor 3 dan 9 tidak memenuhi aspek bahwa pilihan jawaban yang berbentuk angka atau waktu disusun berdasarkan urutan besar kecilnya nilai angka tersebut atau kronologisnya. Soal nomor 11, 12, 13, 14, dan 15 tidak memenuhi aspek bahwa dalam menulis soal bahasa yang digunakan harus komunikatif.

Setelah ditelaah, soal-soal tersebut selanjutnya diperbaiki sesuai dengan hasil telaah. Gambar 4 menunjukkan salah satu perbaikan yang dilakukan berdasar hasil telaah (soal nomor 3).

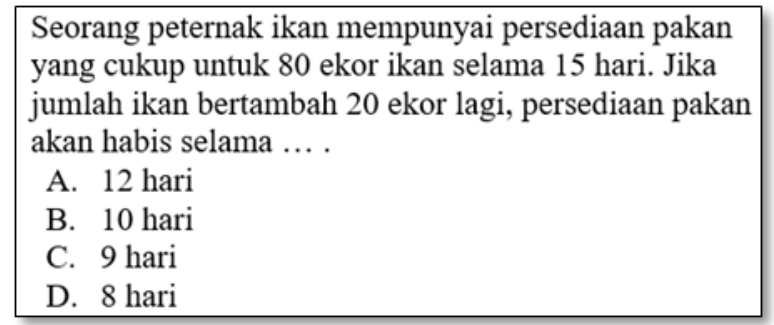

Gambar 5. Soal sebelum diperbaiki

Pada gambar 5 menunjukkan bahwa pilihan jawaban soal nomor 3 tidak disusun berdasar urutan besar kecilnya. Soal tersebut selanjutnya diperbaiki menjadi seperti berikut.

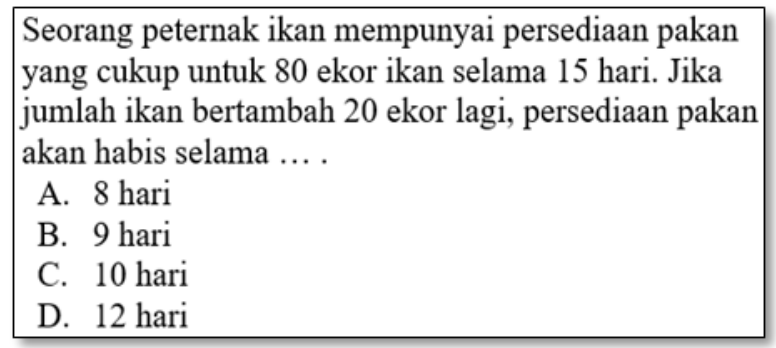

Gambar 6. Soal setelah diperbaiki

Soal-soal yang sudah diperbaiki selanjutnya diujicobakan kepada 58 siswa dari SMP Muhammadiyah 1 Godean dan SMP Muhammadiyah 1 Gamping. Hasil uji coba selanjutnya dianalisis untuk mengetahui karakteristik masing-masing butir berdasar data empiris. Ringkasan karakteristik butir-butir tes yang dikembangkan disajikan pada Tabel 2 .

Tabel 2. Karakteristik Butir

\begin{tabular}{lcc}
\hline No Butir & Indek kesukaran & Daya beda \\
\hline 1 & 0,052 & $-0,207$ \\
2 & 0,931 & 0,372 \\
3 & 0,810 & 0,891 \\
4 & 0,724 & 0,229 \\
5 & 0,138 & 0,009 \\
6 & 0,603 & 0,331 \\
7 & 0,551 \\
8 & 0,517 & 0,817 \\
9 & 0,448 & 0,361 \\
10 & 0,259 & 0,098 \\
11 & 0,103 & 0,205 \\
12 & 0,259 & 0,378 \\
14 & 0,345 & 0,124 \\
15 & 0,397 & 0,114 \\
\hline
\end{tabular}


Butir soal yang baik adalah butir yang tidak terlalu mudah dan tidak terlalu sulit. Apabila soal terlalu mudah maka baik peserta didik yang berkemampuan tinggi maupun berkemampuan rendah semuanya dapat menyelesaikan soal tersebut. Apabila soal tersebut terlalu sulit maka baik siswa yang berkemampuan tinggi maupun yang berkemampuan rendah semuanya tidak dapat menyelesaikan soal tersebut. Akibatnya dari kedua masalah tersebut, soal-soal yang terlalu mudah dan yang terlalu sulit tidak dapat membedakan kemampuan peserta didik yan berkemampuan tinggi dengan peserta didik yang berkemampuan rendah.

Butir soal yang baik dari segi indeks kesukaran adalah butir soal dengan tingkat kesulitan sedang, yaitu berada dalam rentang 0,3 sampai dengan 0,7 (Mardapi, 2008:143; Prabowo, 2016:558). Dengan demikian dari soal-soal yang telah disusun terdapat 7 butir soal yang baik yaitu 6,7,8,9,13,14, dan 15 . Butir soal yang baik dilihat dari daya bedanya adalah butir soal yang memiliki indeks daya beda lebih dari 0,2 (Fernandes, 1984:25-29; Prabowo, 2016:559). Dengan demikian dari soal-soal yang disusun terdapat 10 butir yang soal yang baik (memiliki daya beda baik) yaitu butir nomor 2,3,4,6,7,8,9,11,12, dan 15. Dari butir-butir soal yang telah disusun maka butir yang baik berdasar indeks kesukaran dan daya bedanya adalah butir nomor 6,7,8,9, dan 15. Dengan demikian pelatihan ini telah menghasilkan 5 butir soal yang memiliki kualitas baik berdasar prosedur pengembangan instrumen.

Butir-butir yang telah dihasilkan dalam pelatihan tersebut kemudian diadministrasikan dalam bank soal. Bank soal adalah kumpulan dari soal-soal yang sudah baku dan memiliki karakteristik baik. Menurut Freeman dkk., (2010), bank soal adalah kumpulan item tes yang dianggap berguna untuk penggunaan selama jangka waktu, serta untuk penilaian lintas dan antar kurikuler (Jugar, 2013). Apabila seorang guru akan menggunakan soal-soal tersebut maka guru tinggal memilih soal-soal tersebut sesuai dengan peruntukannya untuk selanjutnya dirakit menjadi sebuah tes dan siap digunakan untuk melakukan pengukuran.

Respons dari peserta pengabdian menunjukkan bahwa melalui pelatihan pengembangan instrumen tes mata pelajaran matematika SMP mampu memberikan keterampilan kepada mereka dalam mengembangkan instrumen penilaian khususnya pada mata pelajaran matematika SMP. Apabila sebelumnya dalam membuat soal mereka hanya mengambil dari buku-buku, maka selanjutnya mereka mampu membuat soal yang terstandar melalui prosedur pengembangan yang baku.

Tingkat pemahaman peserta pelatihan dalam mengembangkan instrumen diukur dengan menggunakan angket dan wawancara. Hasil pengukuran menunjukkan bahwa 85\% peserta tes telah memahami cara mengembangkan instrumen penilaian yang baku. Dengan demikikan, berdasar indikator yang telah ditetapkan, pelatihan yang telah dilaksanakan ini berhasil.

\section{Simpulan dan saran}

Kegiatan pengabdian ini telah memberikan keterampilan kepada guru dalam mengembangkan instrumen tes melalui prosedur yang baku. Kegiatan ini menghasilkan luaran berupa soal-soal matematika SMP yang terstandar yang disimpan di bank soal dan dapat digunakan oleh guru dalam melakukan penilaian mata pelajaran matematika untuk materi perbandingan, hubungan antar sudut, dan keliling dan luas bangun segiempat. Harapan dari peserta tes menunjukkan bahwa kegiatan seperti ini perlu untuk dilaksanakan secara kontinu guna membekali guru dalam mengembangkan tes dan mewujudkan penilaian yang berkualitas.

\section{Daftar Rujukan}

Budi Manfaat, Siti Nurhairiyah.2014." Pengembangan Instrumen Tes Untuk Mengukur Kemampuan Penalaran Statistik Mahasiswa Tadris Matematika”.Jurnal Teknologi Informasi, Volume 5 Nomor 2, Oktober. 2014

Dyah Febria Wardhani, Aminuddin Prahatama Putra.2016. "Pengembangan Instrumen Tes Standar Kognitif pada Mata Pelajaran IPA Kelas 7 SMP Di Kabupaten Banjar". Proceeding Biology Education Conference (ISSN: 2528-5742), Vol 13(1) 2016: 75-82 Seminar Nasional XIII Pendidikan Biologi FKIP UNS 75

Fernandes, H. J. X. (1984). Testing and Measurement. Jakarta: Planning, Evaluation, and Development.

Freeman, A., Nicholls, A., Ricketts, C., and Coombes, L. (2010). Assessing the Feasibility of aTest Item Bank and Assessment. Clearinghouse Medical Teacher, 32(6): 464-466. 
Jugar, R. R. (2013). An Inquiry on the Roles of Personal Test Item Banking (PTIB) and Table of Specifications (TOS) in the Construction and Utilization of Classroom Tests. International Journal of Education and Research, 1(12): 1-8.

Mardapi, Djemari. (2008). Teknik Penyusunan Instrumen Tes dan Nontes. Yogjakarta: Mitra Cendikia Press.

Nur, A. S., Palobo, M. (2018). Pelatihan Analisis Butir Soal Berbasis Komputerisasi Pada Guru SD. MATAPPA: Jurnal Pengabdian Kepada Masyarakat. 1(1): 5-11.

Peraturan Menteri Pendidikan Nasional Nomor 16 Tahun 2007 tentang Standar Kualifikasi Akademik dan Kompetensi Guru.

Permendikbud Nomor 23 Tahun 2016 tentang Standar Penilaian.

Pisowacka, M.K. (2015). The use of the Iteman program in designing a general foreign language placement test. International Journal of Scientific and Research Publications. 5(12): 537-541.

Prabowo, Anggit. (2016). Analisis Butir Soal Ujian Akhir Semester Mata Kuliah Analisis Kurikulum dan Materi Pembelajaran Matematika SMA. Prosiding Seminar Nasional Pendidikan Berkemajuan dan Menggembirakan. Medan, 3 Agustus 2016.

Prabowo, Anggit dan Astuti, Dwi. (2017). Workshop dan Pendampingan Penyusunan dan Analisis Instrumen Hasil Belajar Peserta Didik Berbasis Komputer. Prosiding Seminar Nasional ke-4 Tahun 2017 dengan Tema “Membangun Desa Menuju Indonesia Berkemajuan” ISBN: 978-979-3812-49-6, 25 Oktober 2017 di Hotel Eastparc Yogyakarta.

Prabowo, A., Sunaryo, dan Rahmawati, U. (2017). Pengembangan modul analisis butir soal Dengan menggunakan Item and Test Analysis. AdMathEdu, 7(2): 9-110.

Pulungan , Delyanti Azzumarito.2014. "PENGEMBANGAN INSTRUMEN TES LITERASI MATEMATIKA MODEL PISA" . Journal of Educational Research and Evaluation Vol 3 No 2 (2014)

Rosana, D. dan Setyawarno, D. (2016). Statistik Terapan untuk Penelitian Bidang Pendidikan. Yogyakarta: FMIPA UNY.

Tenri Batari, Nursalam Nursalam, Andi Dian Angriani.2018. "Pengembangan Instrumen Tes Untuk Mengukur Kemampuan Koneksi Matematis".Jurnal Pendidikan Dasar Islam Vol 5, No 1 (2018)

Undang-Undang Nomor 14 Tahun 2005 tentang Guru dan Dosen 